\title{
Women in the Bible as Source of Inspiration for Women Today
}

\author{
Sr. Cecilia Madu OP \\ Department of Sociology Faculty of Social Sciences Benue State University, Makurdi
}

\begin{abstract}
In a world where women's rights have continued to be violated because of their sex, women have continued to struggle with dehumanizing situations in every environment they find themselves. Women play vital roles in the society as they assume five key roles in most societies: mother, producer, home-manager, community organizer and socio-cultural and political activist. Despite women's resourcefulness, their worth has consistently been downplayed and demeaned in the theories, symbols, rituals, religious practices and structures of the society. The situation of women in the society has brought about different reactions and policies like the Convention on the Elimination of all forms of Discrimination against Women CEDAW, and Universal Declaration of Human Rights (UDHR) to mention but a few. Despite all these conventions and policies, women have continued to suffer discrimination and marginalization which has also continued to hamper their contributions to societal development.

The women in the Bible despite all odd made different in the development of their society hence, women today can be inspired and encouraged by the activities of these women portrayed in the Bible, especially Queen Esther, who stood up against every odd, and made difference in their societies. Women today can make a difference in the situations of insecurity, civil unrest, wars, poverty, women illiteracy, violence, and maternal mortality. This could be achieved through mobilizing women from the different organizations that women belonged to in the society whether religious or cultural groups for training in the importance and utilization of healthcare facilities, peacebuilding skills, leadership skills, negotiation skills, different types of skill acquisitions and empowered them to train others in their local communities.
\end{abstract}

\section{Introduction}

Women constitute over half of the world's population and contribute in vital ways to societal development generally, Afolabi et al. (2003). Women assume five key roles in most societies: mother, producer, home-manager, community organizer and socio-cultural and political activist. Despite the vital roles that women play in the society their worth is continually not appreciated in the society. United Nations in marking the millennium in the year 2000 drew up a list of eight millennium goals which both governments and nongovernmental organisations pledged to achieve by 2015. Three of these goals focus mainly on women/girls; to see that girls as much as possible like boys obtain basic education; that the death rate of women at childbirth will be reduced by three-quarters and women will be empowered economically, thereby promoting equality between men and women. The particular reference made to women and girls depicts the position of women and girls in the society. The problems facing women and girls cut through race, religion, culture and nationality. In affirming that women are marginalized in every community, Johnson (2007), states that the problem of inequity faced by women is a human problem because women in every society face the same situations of inequality and fewer privileges/opportunities. Hence, there is no society where men and women share equal opportunities.

In African society, women are in most cases seen as subordinate to their male counterparts. In many communities in Africa, girls are made to understand that there is difference between them and their male counterparts. According to Coper (1997), girls are usually addressed with statements like these: "A girl should sit quietly, talk softly, cover her head, and never disagree with a male." Another statement that girls are always confronted with especially in the Hausa community of Nigeria is "Ba ki gani ke mace ce, she namiji ne," meaning "can't you see you are a girl and he is a man?" implying that a man is superior and this is a refrain repeated to the girl child from her earliest years. She will also hear, " Ke mace ce, gidan wani zaki" meaning, "after all, you are a woman and you are going to someone else's house" or "komai abiniki, gidan wanizaki" meaning, No matter what you do you are going to someone else's house. Another very popular one among Nigerians and may be other communities is "women education ends in the kitchen." These kinds of statements tend to put girls as second class citizens in the communities they find themselves and in most cases demoralize them.

Hence, females, young and old, are made to understand that there is a difference between them and their male counterparts and there are certain attitudes expected of them. To further ascertain the position of women in most African societies especially in Northern Nigeria, Adamu (1999) has this to say, "Once a marriage contract is fully concluded and ended, it is the husband's responsibility to provide for the material and 
sexual needs of his wife. In return, the movement and activities of the wife outside the household need the consent of the husband." Considering this, women become second class citizens and subordinate to their men counterpart.

\section{Why Women in the Bible}

The situation of women as second class citizens, therefore, cuts across all culture and people, even the writers of both Old and New Testaments of the Bible portrayed women as 'second class citizens'. In the bid to combat women's subordination and upheld women's rights many reactions and policies have been created and countries signed in to them with the aim of upholding women. Some of the policies and conventions are Convention on the Elimination of all forms of Discrimination against Women CEDAW, and Universal Declaration of Human Rights (UDHR), gender policy, and many other others. Despite these policies and conventions women's rights have continued to be trampled upon in many states especially in African countries. Women today do not need to remain in the victims' seats and not do anything to help themselves. Hence the women in the Bible could be source of inspiration of women today considering that there are many women in Christianity. Statistics shows that for every one man in the Christianity are nine women. Therefore, since there are many women in Christianity and the bible is the key book of Christianity, women in the bible are then vital source of up-liftment for women today.

\section{The Status of Women in Old Testament of the Bible}

Women in the Bible were in most cases depicted as second class citizens because they were expected to just listen and not speak. Thus one of the writer in the Bible states, "Let your women keep silence in the churches: for it is not permitted unto them to speak; but they are commanded to be under obedience, as also with the law. And if they will learn anything, let them ask their husbands at home: for it is a shame for women to speak in the church" (1 Corinthians 14:34-35). Despite the relegation of women in the Bible, many women played significant roles as were portrayed in both Old and New Testaments. The Bible in both Old and New Testaments laid little emphasis on the significant roles played by women in the Bible while most of the Bible authors paid more attention on what women should not do or be. The significant roles played by women in the Bible were not displayed clearly except for the role of Mary, the mother of Jesus.

The Bible writers dealt more on what women are not supposed to do, thereby representing them to be passive without playing any role in the Bible. In many passages in the Bible, women were expected to be quite and listen to the men. Thus it says, "Let the woman learn in silence with all subjection. But I suffer not a woman to teach, nor to usurp authority over the man, but to be in silence. For Adam was first formed, then Eve. In considering the situation of Adam and Eve in the garden, Eve the woman was also seen to be the one who was deceived to eat the fruit. Adam was not deceived, but the woman being deceived was in the transgression" (1Timothy 2:11-14). Timothy, the author of this passage in the Bible depicts the position of women and even showed how Eve (woman) was blamed for the sin committed by her and Adam (man). Eve was said to have play a significant role in the salvation history of the world because she was the mother of all creation.

The writers in the Bible continued to depict women as subordinate to their male counterparts. They represented women as inferior to men and therefore the Bible says, "And the Lord spoke unto Moses, saying, Speak unto the children of Israel, and say unto them, when a man shall make a singular vow, the persons shall be for the Lord by thy estimation. And thy estimation shall be of the male from twenty years old even unto sixty years old, even thy estimation shall be fifty shekels of silver, after the shekel of the sanctuary. And if it be a female, then thy estimation shall be thirty shekels. And if it be from a month old even unto five years old, then thy estimation shall be of the male five shekels of silver, and for the female thy estimation shall be three shekels of silver. And if it be from sixty years old and above, if it be a male, then thy estimation shall be fifteen shekels, and for the female, ten shekels" (Leviticus 27:1-7).

Considering this passage from the Old Testament, one would see that women were considered to be completely inferior to men in the whole of the Old Testament of the Bible. However, the position of women in the Old Testament community did not prevent the women from playing courageous and positive roles in their communities that made great difference for the people in the communities. For instance, Deborah was the only woman prophet and great army leader in her community and Esther was a great woman who also saved her people from the hands of the king.

There were many women in the Bible who played different important roles and among them were women like Sarah, Claudia, Deborah, Esther, Jael, Jephthah's daughter, Judith, Miriam, Naomi, Pharaoh's daughter, Priscilla, Rachael, Rebecca, Rahab, Ruth, Salome, Susanna, the Egyptian midwives, and Hanna the mother of Samuel. All these women in their lives played great roles that brought salvation to their people and to us today.

For instance, Prophetess Deborah, who prophesied to Barak that God will Deliver Sisera into his hands. Thus the Bible says, "Now Deborah, a prophetess, the wife of Lappidoth, was judging Israel at that time" 
(Judges 4:4). Deborah was equally a judge in Israel at this time. At the time of Deborah's reign in Israel, God gave victory to His people through a woman named Jeal who killed Sisera; "But Jael, Heber's wife, took a tent peg and seized a hammer in her hand, and went secretly to him and drove the peg into his temple, and it went through into the ground; for he was sound asleep and exhausted; So he died" (Judges 4:21).

Eve, though deceived, played a role because her letting herself to be deceived led to the coming of Christ to redeem the whole of human race. It is said that through her disobedience all human disobeyed God. Eve played a great role in the salvation of mankind as the first woman and mother of the human race. She is a sign of human imperfection and the reality of life. She was the source of Christ because if she had not allowed herself to be deceived by the serpent we may not have Christ and possibly may not have come to know God the way we do today.

Pharaoh's daughter and Miriam, Moses' sister, were other women who played great roles in the salvation of their people and in bringing about the plan of God. Miriam took the risk of watching her brother at the Nile and even going up to Pharaoh's daughter, to ask if she could get a Hebrew woman to take care of the child for her. She could have implicated herself, since, according to the Bible, she appeared at the scene as soon as the child was picked. Thus it says, "She saw the basket among the reeds and sent her slave girl to get it. She opened it and saw the baby. He was crying, and she felt sorry for him. This is one of the Hebrew babies, she said. Then his sister asked Pharaoh's daughter, "Shall I go and get one of the Hebrew women to nurse the baby for you?"(Exodus 4:5b-7). Pharaoh's daughter played a great role too. Knowing that the child was one of the Hebrew's children and that her father had issued an order for them to be killed, she would have just handed the child to her father's servant to be killed but kept the child thereby violating her father's order. In violating her father's orders she played a role in the lives of the Israelites who were finally led out of the land of slavery by this same Moses saved by Pharaoh's daughter.

The Hebrew midwives were another group of women who played great role in the Bible. They disobeyed the order of the king who is an authority to be obeyed by sparing the lives of the babies born by the Hebrew women. The king of Egypt said to the Hebrew midwives, whose names were Shiphrah and Puah, "When you help the Hebrew women in childbirth and observe them on the delivery stool, if it is a boy, kill him; but if it is a girl, let her live." The midwives, however, feared God and did not do what the king of Egypt had told them to do; they let the boys live. Then the king of Egypt summoned the midwives and asked them, "Why have you done this? Why have you let the boys live?" The midwives answered Pharaoh, "Hebrew women are not like Egyptian women; they are vigorous and give birth before the midwives arrive. (Exodus 1:15-19)

Miriam, the prophetess took the tumbrel in her hand, and all the women went out after her with tumbrels and dancing in thanksgiving to God for rescuing the Israelites from the hands of Pharaoh and all his army. Miriam answered them, sing to the LORD, for He is highly exalted; the horse and his rider He has hurled into the sea." (Exodus 15:20-21). Miriam is here depicted as a great woman leader who motivated women around her to sing praises to God.

Ruth and Naomi played role in the salvation of humankind since it was through them that David the ancestor of Jesus came (Ruth 4:13,17). Rebecca equally played a great role of helping Jacob claim the blessing which led to the fulfillment of God's plan in Jacob's life and in the lives of the Israelites (Genesis 27). Rahab was harlots who played great role in the lives of the people. Rahab hid the spies sent by Joshua to spy Jericho (Joshua 2:1-2).

Perhaps the most daring and enduring woman character in the Bible is Esther. She single-handedly conquered Haman, the man who hated the Jews with passion, and she fought for the Jews' freedom. Through Esther's heroic act, Mordecai escaped death, and the Jews in the city gained their freedom. Such bravery displayed by Esther remains a great source of inspiration to millions of women in the world, especially African women who continue to struggle to free themselves from the stultifying shackles of patriarchy and the vast insecurity everywhere in Africa.

\section{The Status of Women in the New Testament of the Bible}

Looking through the Bible and digesting the stories, one would see that women played great roles in their communities even though they were not to be heard in the society or given positions of authority. The New Testament has great stories of women who played great role that made difference in the lives of the people in their communities. Among the women were Mary the mother of Jesus, Mary Magdalene, Elizabeth, Jairus daughter, Anna, Lydia, Martha, Mary, Dorcas and the woman at the well.

Mary the mother of Jesus accepted the call to play a role that will change the world with all its challenges and difficulties. Her role brought about change in her immediate community and in the world at large even up to date (Lk1)

Mary Magdalene was one of the first evangelists, since she was one of the women who ran to the tomb early in the morning, and the person Jesus sent to preach the good news of His resurrection to the other apostles.(Mt:28:1-7; Mk 16:5-7) 
The vital roles played by women as portrayed in the New Testament were mainly by the writer of Luke; hence the Gospel of Luke will be used to depict the role played by women in the New Testament.

Luke portrayed women in an extremely progressive and almost modern fashion, giving them new identity and new social status. Even as the Gospel highlights women as included among the followers of Jesus, subjects of his teaching and objects of his healing, it deftly portrays them as models of subordinate service, excluded from the power center of the movement and from significant responsibilities. Claiming the authority of Jesus, this portrayal is an attempt to legitimate male dominance in the Christianity of the author's time (Schaberg 2002).

Luke can be said to be a feminist, in line with the definition of feminist given by Schaberg (2002) "as men and women committed to eliminating sexism in their relations with one another and in the structures of their faith communities and society." In line with the above definition of feminist then, Luke, the author of the third Gospel, is a feminist because he among the four evangelists wrote more about women and their role in the ministry of Jesus and the early church. He did not write about them in his Gospel as a means of depicting them as models of subordinate service, excluded from the power center of the movement and from significant responsibilities (Schaberg, 2002). He showed that women as well as men played some roles in the building of the church and her ministry, which is the ministry of Jesus. This ministry of Jesus includes his healing, teaching, preaching in both words and deeds, touching, and praying.

Luke makes reference to women in many passages of his Gospels, in as many as forty-two passages, of which twenty-three are unique. Some passages are those concerning Elizabeth (Luke 1:5-7, 24-25, 39-45, 57-66), Mary (1:26-56, 2:1-52), Ana (2:36-38), Widows (7:11-17, 18:1-8), Mary Magdalene, Joanna, Susanna, and other Galilean women who ministered (8:1-3), Mary and Martha (10:38-42), women at the death and burial of Jesus who also discovered the empty tomb $(23: 49,55-56,24: 1-12)$ to name some of the prominent ones. He also gave the account of women's roles in the early church in Acts. Reid (2008), affirms this saying, "Only Luke, in his second volume, gives us the traditions about the women disciples in the upper room (Acts 1:14); Sapphira (5:1-11); the slave girl of Philippi (16:16-24); Tabitha (9:36-43); Lydia (16:13-15, 40); Damaris (17:34); Priscilla (18:2, 18, 26); and Philip's four daughters (21:8-11).

The ancient society in which Luke lived was a patriarchal society. Thus Moltmann (1998) claimed that the Bible was written or given its final form in a predominantly patriarchal culture. It contains a number of sexist remark i.e. remarks which suppress women, for example, in the Old Testament, women are seen as wives and as their husband's personal properties.

Therefore, Luke, starting his Gospel with the powerful stories of women, credits him with the recognition of women as among the societal prophets Anna (Lk 2:36) and disciples (Lk 6:13). To show this equality among men and women in the early Christian society, he identifies Priscilla as a teacher of the good news (Acts 18:28). He continued to challenge the society in which he lived by depicting women in Jesus' ministry as equal with men by pairing many characters and events; the appearance of the angel to Zechariah (1:11-20) and to Mary (1:26-38). These episodes of appearances show that God does not in any way choose to speak to women through their husbands or men, but speak to them directly. Luke continued to show this in his Gospel. He also continued this depiction of equality between women and men in Jesus' ministry by having two lists of Jesus' disciples; one of men (6:12-19) and one of women (8:1-3).

Luke continued to promote the cause of women in his society by praising, defending, and reassuring women through his references to widows $(2: 37 ; 4: 25-26 ; 7: 12 ; 18: 3,5 ; 20: 47 ; 21: 2-3)$; the sinful woman $(7: 36-$ $50)$ and the woman bent over (13:16); all of these women are people that the society had little or no regard for. In a society where men (husbands) and child-birth are the defining elements for women, a widow or a barren woman is practically nobody, since she has no man or child to give meaning to her life. By making reference to these people, Luke promoted the cause of women and challenged his readers to see beyond where they stood. The episodes of Elizabeth, who was barren and passed the age of child birth but later conceived, and of Mary, a young girl not fully married were another way Luke clothed women with dignity in a culture where they had little place. He mentioned many more women by name unlike Mark, Matthew and John who never mentioned neither Elizabeth nor Anna in their Gospels.

Schaberg (2002), continued to ascertain that women even though portrayed as not being commissioned by Jesus to preach, did not stop their mission of preaching since Mary was commissioned by God through the angel to preach and that was the reason she was sent to her cousin Elizabeth. Mary's presence in Elizabeth's house was a great proclamation of the good news that she was the first bearer. Mary was commissioned by God through the power of the Holy Spirit like all the prophets of old; Jeremiah (1:4-6), Isaiah (6:5-8), and even Zechariah (Lk1:18-20) because they either doubted or were afraid of what was said to them until they were commissioned to proclaim what they have been told. This shows that women have a significant role to play in bringing good news to people around them. This good news could be in the form of encouragement to those suffering or a word of advice to people around them that can lead to peace and joy in the society. 
Reid (2008) argued that in the remainder of the gospel of Luke, the writer did not portray Jesus as reversing the status quo, so that those on the bottom are now on top. Rather, his Gospel proclaims inclusivity, where no one is automatically in or out, up or down. All are invited as equal participants, across boundaries of status, gender, and race. This then shows that both men and women need to contribute to the development of peace in a world full of insecurity and wars.

Luke played a great role in the Bible to depict the important roles women played in the salvation history and in the early church. In the annunciation of John, Zachariah was made speechless because he doubted (Lk1:20) but Mary was not made speechless when she doubted; instead, she was helped to believe (Lk1:35-36). Even though, Zachariah was made speechless for Elizabeth to speak in public among her kinsmen, thereby proclaiming the good news of God to them (Lk 1:60), it doesn't in any way imply that one sex has to be suppressed for the other to thrive. It only gave the woman the opportunity to express her faith and ability.

\section{Sociological Implication of the Role of Women in the Bible for Women Today}

Accepting the fact that the experiences of women differ from place to place, one needs to be conscious of one pitfall which could be the tendency to universalize the experience of women, forgetting that race, class, education, age, and social location are also influential factors to the position of women in the society.

Considering the way women are portrayed in the Bible and the roles they played in the Biblical communities, it will not be out of place to call on women today to look beyond where they are standing to see themselves as people who have power to bring about positive changes in the society. There are many needs in the society today like security challenge, wars, poverty, maternal death, infant mortality, hunger, and many others. In 1990, the United Nations released statistics showing the position of women in the world as follows: women make up half the world's population, women work three-fourths of world's working hours one tenth of world's salary; and constitute two -thirds of the world's illiterate adults. Even though women have to deal with the mentioned situations as enumerated by the United Nations, they also have more issues to deal with in the different societies such as gender violence, forced prostitution, trafficking, rape and murder, especially by their close male partners. These are issues that women need to play active roles in reducing better still in eradicating in the society today especially in Nigeria.

\section{Conclusion /Recommendations}

Considering all that women go through in the society, the victims' seats are not meant for them for they have great powers within them to conquer every huddle. Women today can make a difference like the women in the Bible who brought about changes in their communities. Yes the women in the Bible, stood up against all odds and made the difference in their society. The women in Africa and especially in Nigeria can do the same as the women in the Bible. Nigerian women must find their voice, speak up against oppressions in the society and make a difference in Nigeria.

Considering the situation of security in Nigeria today, women in Nigeria have great responsibilities to see that peace returns to the country. As mothers, sisters, daughters and wives in the society, they need to rise up to the challenges of making their voices heard by their immediate communities through talking to their fathers, brothers, sons and husband about peace.

Women should figure out ways for achieving high level of mobilization of women at all levels especially local and community levels. For example the group 'Women for Change' could be a forum to mobilize women for peace building in the society.

The women leaders in every community should be equipped with relevant information and experience built through broad based interaction which will become useful in mediating the local networks for peace building objective. Then like the women in the Bible, the women today will be equipped to work for peace in their society.

Women should be empowered through education to understand the advantages and disadvantages of early marriage so as to prevent infant mortality and maternal deaths. There should be a centre for adult literacy in every community for women especially those married to acquire education.

Through these mediums, social support systems will be built for women who feel they can do nothing to alleviate the situation around them to contribute their quota for the growth and development of the society.

Women in different places; rural and urban should be trained in the importance of the utilization of health facilities, so that the high rate of maternal death and child mortality could be reduced or better still eradicated in the society. 


\section{Reference}

[1]. Adamu Fatima (1999). A Double-Edge Sword: Challenging Women's Oppression within Muslim Society in Northern Nigeria. Gender and Development Journal Vol. 7, No. 1.

[2]. Coper Barbara M. (1997). Marriage in Maradi: Gender and Culture in a Hausa Society in Niger, 1900-1989 Nigeria Heinemann.

[3]. Getty-Sullivan, Mary Ann (2001). Women in the New Testament: Collegeville, Minneapolis MN: Liturgical Press.

[4]. Johnson E. A. (2007). Quest for the Living God: Mapping Frontiers in the Theology of God. New York: The Continuum International Publishing Group Inc

[5]. Moltmann-Wendel, Elisabeth (1982). The women around Jesus: Reflections on Authentic Personhood [translated by John Bowden from the German]. London: SCM Press.

[6]. Powell M.A (1998). Introduction to the Gospels Minneapolis, MN: Fortress Press.

[7]. Reid Barbara (1996) Choosing the Better Part: Women in the Gospel of Luke Collegeville, Minneapolis MN: Liturgical Press

[8]. Schaberg Jane (2002). The Resurrection of Mary Magdalene: Legends, Apocrypha, and the Christian Testament. New York: The Continuum International Publishing Group Inc

[9]. www.uscongregations.org/key.htm 